Article

\title{
Analysis of Socioeconomic Impacts of the FSC and PEFC Certification Systems on Business Entities and Consumers
}

\author{
Jakub Michal ${ }^{1}{ }^{1}$, David Březina ${ }^{1}$, Dalibor Šafařík ${ }^{1}$, Václav Kupčák ${ }^{1}$, Andrea Sujová ${ }^{1, *}$ and \\ Jitka Fialová 2 (D) \\ 1 Faculty of Forestry and Wood Technology, Department of Forest and Wood Products Economics and Policy, \\ Mendel University in Brno, 61300 Brno, Czech Republic \\ 2 Faculty of Forestry and Wood Technology, Department of Landscape Management, Mendel University \\ in Brno, 61300 Brno, Czech Republic \\ * Correspondence: andrea.sujova@mendelu.cz; Tel.: +42-0545-134-312
}

Received: 28 June 2019; Accepted: 28 July 2019; Published: 30 July 2019

\begin{abstract}
The article discusses the issues of effectiveness of the FSC (Forest Stewardship Council) and PEFC (Programme for the Endorsement of Forest Certification) certification systems in relation to enterprises and the level to which the systems which present sustainability as a part of their ethos are accepted by consumers. The justifiability and topicality of this issue result from the increasingly strong interest in sustainability of the society as a whole as well as from the long-term vision of sector policies with respect to meeting the objectives of sustainable development. The increasing demand for natural resources exerts pressure on our planet. Sustainability is hence essential for our future and has long been in the centre of the European project. Its economic, social and environmental aspects which form the common objective of society have been acknowledged in EU agreements. A principal document of a global nature is the 2030 UN Agenda for Development, a sustainability programme which has the sustainability of forest ecosystems established in its Goal 15: Protect, restore and promote sustainable use of terrestrial ecosystems, sustainably manage forests, combat desertification, and halt and reverse land degradation and halt biodiversity loss. Visions, direction and goals of sustainable development have also been stipulated in the Paris Agreement on climate change (COP21), in the Addis Ababa action programme and in The Future We Want declaration, namely in its Chapter II, which appeals to enterprises and industries for developing strategies which would contribute to sustainable development. This study aims to analyse and assess the justifiability of the existence of certification systems in relation to processing operators and end consumers in the Czech Republic. From the results of the study, it can be concluded that, despite the strong representation of selected certification systems in the Czech Republic, their effectiveness in economic, social and environmental terms is not perceived exclusively positive by businesses and consumers.
\end{abstract}

Keywords: sustainable management; forest sustainability; FSC; PEFC; effectiveness

\section{Introduction}

The contemporary society intensively exploits both renewable and non-renewable resources. Its ecological footprint is enormous due to the poor management of natural resources. On the basis of the Global Footprint Network (GFN) report, it can be said that the humankind will run into a so-called ecological debt as early as on 1 August 2019 (this means that on that date it has exhausted all natural resources that the biosphere is able to replace in one year). In the case of the Czech Republic, the figures are yet more sceptical indicating that the country has already been in the ecological debt since 17th April, which ranks the country in 26th place worldwide [1]. Joppart [2] claims in the WWF (World 
Wide Fund for Nature) European Policy Office report that if everyone in the world lived like the people of the EU then 10 May 2019 would have been the day when the humankind had exploited the annual budget of the nature. The issues of sustainability and efficient and sensible management of resources pose a serious problem in the EU, which needs to be addressed in a complex manner and within a short time horizon.

Besides the very negative figures, the situation in the area (management of resources) is mainly demonstrated by the greenhouse gas emissions and the excessive food wastage. Europe has become a prevailingly importing country [3], which, in the long-term view, could result in its increasing instability and unsustainable system considering the hardly predictable geopolitical conditions. The basic definition of sustainable development establishes three pillars of sustainability, specifically the economic pillar, the social pillar and the environmental pillar. Consequently, principles based on finding the balance between its economic, environmental and social aspects appear crucial to sustainable development. According to Mezeřický [4], however, the basic pillars of sustainability sometimes get into mutual conflict (for example, the influence of nature protection shall be assessed prior to constructing a technology-transport network). All initiatives to assess the balance of those pillars proceed from the need to monitor the actual impacts of giving preference to the individual pillars on sustainability. These preference matters are currently topical in Europe due to the problems caused by climate change. In Europe, forest ecosystems have major impact on its problems with sustainability related to climate changes. By analogy, a growing extent of damages caused by wind in the even-aged monocultures in Northern and Central Europe, changes in fire mode in the extensively managed forests in the Mediterranean area or a sharp increase in the extent of damages of multifunctional managed forests in central Europe caused by drought and pests are worth mentioning [5]. Looking for a global analysis of the sustainability issues from the perspective of forest ecosystems, the most suitable one is the Goal 15 of the 2030 UN Agenda, in which Europe alone only shows one indicator with no and small progress while the global average is mainly worsened by Southeast Asia, North Africa and the landlocked developing countries (LLDCs). These facts were mentioned in the FAO ( Food and Agriculture Organization) 2018 report [6] and are shown in Table 1.

The facts provided in Table 1 reveal that there is only a single indicator with a negative development in the European context: the ratio of forest areas according to the long-term forest management plans. The deteriorating situation can be ascribed to numerous occurrences of disasters primarily caused by abiotic agents and insect or fungal pests, which particularly troubled central and western Europe [7]. The aforementioned three pillars of sustainability get into a conflict of interests of the interested parties mainly due to the deteriorating condition of forest ecosystems in Europe. Their direct impact is often considered to be the cause or effect of the confrontation and the need to strike balance between them is often challenged in the current conditions. The interconnection of the three pillars of sustainability was analysed and monitored using selected examples within the scope of the research surveys conducted in the Czech Republic. To satisfy the needs to interpret the outputs of the research surveys carried out by the team of authors, it is necessary to clarify the current situation regrading sustainability in the Czech Republic.

Forest management in the Czech Republic is currently undergoing a very specific period. Forests have been changing rapidly due to disasters and increasing drought. The current problems share a typical feature: the sustainability. Although the sustainable management system obviously cannot be considered the main cause of the current problems, it's appropriate strategy could help solve this situation to a large extent. At the national level, the sustainable management system is incited by the law. Sustainability was already defined in the Czech legislation in Act No. 17/1992 Coll. on the environment, which stipulates the following: "Permanently sustainable development of the society is that development which preserves for present and future generations the possibility of meeting their basic needs, and at the same time, does not reduce the diversity of nature and preserves the natural functions of ecosystems" [8]. Similarly, environmental policy-making also concentrates on decisions regarding market or even voluntary tools for sustainable management more often despite the 
uncertainty about their true effect [9]. At the national level, there is an option between two voluntary tools for sustainable development: the FSC (Forest Stewardship Council) certification and the PEFC (Programme for the Endorsement of Forest Certification) certification.

Table 1. Progress towards sustainable forest management for sub-indicators of SDG (Sustainable Development Goals) 15 (source [6] modified by authors).

\begin{tabular}{|c|c|c|c|c|c|}
\hline $\begin{array}{l}\text { SDG Regional } \\
\text { Grouping }\end{array}$ & $\begin{array}{c}\text { Forest Area } \\
\text { Net Change } \\
\text { Rate }{ }^{* 1}\end{array}$ & $\begin{array}{c}\text { Aboveground } \\
\text { Biomass Stock } \\
\text { in Forest }\end{array}$ & $\begin{array}{c}\text { Proportion of } \\
\text { Forest Area } \\
\text { Located in Legally } \\
\text { Established } \\
\text { Protected Area }\end{array}$ & $\begin{array}{c}\text { Proportion of } \\
\text { Forest Area under } \\
\text { Long-Term Forest } \\
\text { Management } \\
\text { Plans }\end{array}$ & $\begin{array}{c}\text { Forest Area under } \\
\text { Independently Verified } \\
\text { Forest Management } \\
\text { Certification Schemes }{ }^{* 2}\end{array}$ \\
\hline World & $\begin{array}{l}\text { No/small } \\
\text { change }\end{array}$ & $\begin{array}{l}\text { No/small } \\
\text { change }\end{array}$ & Positive change & Positive change & Positive change \\
\hline North America & Positive change & Positive change & No/small change & Positive change & Positive change \\
\hline Europe & Positive change & Positive change & Positive change & No/small change & Positive change \\
\hline $\begin{array}{l}\text { Latin America } \\
\text { and the } \\
\text { Caribbean }\end{array}$ & $\begin{array}{l}\text { No/small } \\
\text { change }\end{array}$ & Positive change & Positive change & Positive change & Positive change \\
\hline Central Asia & $\begin{array}{l}\text { No/small } \\
\text { change }\end{array}$ & Positive change & No/small change & No/small change & No certified areas \\
\hline South Asia & Positive change & $\begin{array}{l}\text { Negative } \\
\text { change }\end{array}$ & No/small change & Positive change & Positive change \\
\hline Eastern Asia & Positive change & Positive change & Positive change & Positive change & Positive change \\
\hline Southeast Asia & $\begin{array}{l}\text { Negative } \\
\text { change }\end{array}$ & $\begin{array}{l}\text { Negative } \\
\text { change }\end{array}$ & Positive change & No/small change & Negative change \\
\hline Western Asia & Positive change & Positive change & Positive change & Positive change & Positive change \\
\hline North Africa & $\begin{array}{l}\text { Negative } \\
\text { change }\end{array}$ & $\begin{array}{l}\text { No/small } \\
\text { change }\end{array}$ & No/small change & Positive change & No certified areas \\
\hline $\begin{array}{l}\text { Sub-Saharan } \\
\text { Africa }\end{array}$ & $\begin{array}{l}\text { No/small } \\
\text { change }\end{array}$ & $\begin{array}{l}\text { No/small } \\
\text { change }\end{array}$ & Positive change & Positive change & Negative change \\
\hline $\begin{array}{l}\text { Oceania, } \\
\text { excluding } \\
\text { Australia and } \\
\text { New Zealand }\end{array}$ & $\begin{array}{l}\text { No/small } \\
\text { change }\end{array}$ & $\begin{array}{l}\text { No/small } \\
\text { change }\end{array}$ & Positive change & Positive change & Positive change \\
\hline $\begin{array}{l}\text { Australia and } \\
\text { New Zealand }\end{array}$ & Positive change & Positive change & Positive change & Positive change & Positive hange \\
\hline $\begin{array}{l}\text { Landlocked } \\
\text { developing } \\
\text { countries } \\
\text { (LLDCs) }\end{array}$ & $\begin{array}{l}\text { Negative } \\
\text { change }\end{array}$ & $\begin{array}{l}\text { No/small } \\
\text { change }\end{array}$ & Negative change & Positive change & Negative change \\
\hline $\begin{array}{l}\text { Least-developed } \\
\text { countries } \\
\text { (LDCs) }\end{array}$ & $\begin{array}{l}\text { No/small } \\
\text { change }\end{array}$ & $\begin{array}{l}\text { No/small } \\
\text { change }\end{array}$ & Positive change & Positive change & Positive change \\
\hline $\begin{array}{l}\text { Small Island } \\
\text { developing } \\
\text { states (SIDS) }\end{array}$ & Positive change & $\begin{array}{l}\text { No/small } \\
\text { change }\end{array}$ & Positive change & Positive change & Negative change \\
\hline
\end{tabular}

${ }^{*} 1$ calculated using compound interest formula; ${ }^{2} 2$ includes areas certified under FSC and PEFC certification schemes.

A forest certification is perceived as a voluntary mechanism which arose from the worries about sustainable management of forest resources. The main goal of the certification is to confirm that the activities performed in a specific forest area meet the standards stipulated by third party organisations. Yet the opinions of individual entities on the certification differ when it comes to the economic impacts of this voluntary mechanism as noted by Vlosky et al. [10]. Cashore et al. [11] analysed the justifiability of the use of the certification as either an environmental or economic tool for streamlining business management. Monitoring and analysing the use of certification systems and their true impact on sustainable development thus seem an appropriate approach to formulate recommendations for the certification systems representatives.

In the Czech Republic, the environmental, social and economic impacts of forest certifications were studied by Mikulová et al. [12]. According to their analysis, the opinions on certifications differ significantly depending on the size of the managed forest area of the selected certified entity. The results indicate that the entities with less than 50 ha perceive the forest certification as less effective from the environmental and social perspective. The environmental and social perspectives of the 
certification are mainly reflected in the protection and improvement of the environment, of the social responsibility and of public opinion on management of natural resources. In the case of enterprises which process or trade certified wood raw material, the most frequently analysed and researched areas addressed by numerous authors (e.g., References [13-23]) were the reasons for opting for a certification and the real economic impact in the form of costs. Vidal et al. [24] argues that the costs of the certification are also linked with the size of the entity in the case of both certified managed forest areas and enterprises with the Chain of Custody certification, with a general trend towards lower costs in the case of larger companies. While direct costs of the certification are the main concern of forest entities before the initial phase of forest certification, the situation with indirect costs in the case of the C-o-C (Chain of Custody Certification) certification of the consumer chain of wood is far more complicated. The difference in the costs is caused by the fact that it is partly a product certification, i.e., a product is certified providing it has the required qualities, and partly a system certification since the normative documents stipulate requirements on processes and on the level of management [25]. This can be ascribed to the fact that the costs are cumulated differently with a product certification and with a management system certification. The amount of indirect costs of the certification of the consumer chain of wood strongly depends on whether the organisation has already implemented a management system pursuant to the standards of the ISO 9000 series, the ISO 14,000 series, the EMS (Environmental Management System) or the EMAS (Eco-Management and Audit Scheme). Supposing that the organisation has already been certified according to the ISO 9000 or 14,000 series of standards, the PEFC certification system recognises the fulfilment of some of its requirements if a certificate of the ISO series (CFCS 1004:2006, 2008) is submitted. Provided that the organisation has implemented the EMS system or the EMAS system, the certification process is substantially simplified [26].

The last part of the source data used in the article relate to the consumers' willingness to accept certified products. If the consumer behaviour affects the demand for products, then opting for certified products has a significant impact on the producers' interest in reacting to the customers' requirements for certification. The consumer behaviour in the pro-environmental choice segment was studied by Steiner et al. [27]. Although the research and the consequent publications did not primarily concentrate on consumers' perceptions of certification systems, they dealt with some facts of the psychography research and of the development of cognitive biases in characterizing consumer segments in the "environmental" sector. Finding the dependence of the preferences on price or on gender, education or age category of respondents is a very important criterion in deciding on the environmental product selection process.

However, it is often difficult for a consumer to identify the right choice, which means that the price is often preferred to environmental interests. The issues of brand recognition and consumers' preference to it were addressed by numerous authors (e.g., References [28-33]). The publications by the mentioned authors prevailingly focus on studying consumers behaviour in creating a linkage to a certain brand.

The most widely used definition and model of the "brand personality" concept is the one formulated by Jennifer Aaker, a social psychologist, in 1997. She characterised the concept as a "set of human characteristics which the consumer associates with the brand" [34]. Building on the dimensions of brand knowledge according to Keller [35], it can be stated that the brand recognition and the brand image belong to the basic components of brand knowledge; without them, a brand does not have any justification for the customer to become an article demanded in the future for its popularity or interestingness. The recognition of a brand (logo, symbol) which represents environmental interests, social responsibility and sustainability was also addressed by the research carried out by the authors of this article; the results of the research are described and interpreted in a separate part of this article. The aim of this paper is to present some of the outcomes of the project intentions of the authors from 2017 and 2018. The first project intent of the outputs was the analysis of consumer behaviour in the wood products segment with respect to consumers' interest in consumption of products made of certified raw wood material. The part of questionnaire surveys dealing with sustainability matters related 
to wood products concentrated on the FSC and PEFC certifications, which represent the interests of sustainable development by the virtue of their criteria. The second project intent of 2018 was to analyse the socioeconomic impacts in the timber product segment with the aim to assess the positive and negative effects of certified wood raw material in businesses. These outputs were analysed with respect to the specific indicators of economic efficiency of the certified businesses as well as to the facts which most discourage the non-certified businesses from accepting such tools. Information from these project intentions aims to assess and evaluate the actual effects of the existence and use of the certification systems of the selected country

\section{Materials and Methods}

\subsection{Materials and Methods of Article}

This article adopts a method which reflects the process of preparation of analytical studies as far as possible. The objective of the method preparation was to harmonise the theoretical information sources accessible to public prevailingly in expert publications with the practical primary and secondary data collected in the Czech Republic. By comparing the information, the authors aimed to define the problematic areas of the certification systems and their real social, economic and environmental effectiveness.

\subsection{Materials and Methods of Questionnaire Surveys}

Two concepts of a questionnaire were prepared to help identify the mentioned parts of the analysis. Subsequently, the questionnaire was distributed to the interested parties in the researched field. The reason for choosing the questionnaire survey method was that it allowed for a nationwide data collection, which would be very costly in the case of direct confrontations of respondents in the field and would not guarantee the anonymity transparently. The content of the questionnaire and the questions of both the surveys were based on a comparison of the results of studies not limited to the field of certification and conducted by both Czech and foreign authors. The objective was to get a structured questionnaire which would work with questions and responses that would clearly show the impact of certification systems on the surveyed areas of analysis. When collecting the data, the authors maintained the statistical significance of the monitored sample of respondents with an accurate confidence interval. The results of the analyses were obtained from two projects prepared at the Department of Forest and Wood Products Economics and Policy between the years 2016 and 2018. The first project from which the resulting data were obtained focused on analysing the consumer behaviour in the wood product segment in the context of consumers' interest in products made of certified wood raw material. The other part of the outputs interpreted in the Results section was obtained from a project which included an analysis of the socioeconomic impacts for business entities in the segment of wood products in the context of an assessment of the advantages and disadvantages resulting from wood raw material certification. When defining the statistically significant sample, the authors proceeded from the method of surveysystem.com [36]. In the case of consumers, the sample of respondents was defined using the last assessed information about the working age population of 2015 (ČSÚ), specifically the number of $6,997,700$ with the confidence interval of $5 \%$. In total, 404 questionnaires were collected of the required number of 384 defined by the calculation. Consequently, it can be said that the conditions for statistical significance were met. The method of the other questionnaire survey was substantially different. The data collection was more complex and more time-consuming. To maintain the informative nature of the survey, it was necessary to create a database of both certified and non-certified respondents. E-mail addresses of almost all the entities certified according to the FSC or the PEFC were collected from the public databases of the certification systems. They were completed with an internal database of enterprises active in the field of wood-processing industry created by the authors of this article. The database of enterprises included 723 addressed respondents, of which 127 filled in the questionnaire. In compliance with the method of the surveysystem, the 
confidence interval of $8 \%$ had to be used to satisfy the requirements on a statistically relevant sample; however, this did not necessarily mean a deviation from the informative value of the data thanks to the complexity of the information obtained from the enterprises. The questionnaires were prevailingly distributed in electronic form via the paid platform of survio.com $[37,38]$, which provides an umbrella for many nation-wide surveys in the field of data collecting using questionnaires. A direct distribution of the questionnaire by means of personal confrontations was mainly used with the consumer line of the analysis. The surveys demonstrated that there were several borderline problem areas.

\subsection{Supplementary Materials}

Consumer survey inquiry process:

- Defining the exact sample size of the respondents in working age of selected country (Czech Republic) to maintain the value of the research survey.

- Implementation of questionnaire research on the selected national sample of respondents, with all the criteria selected and conditions for the verification of whole project proposal.

- Summarizing data in graphical and table processing, defining the extent of the questionnaire research success, comparing data with possible variances and the causes of possible deviations.

- Statistical data processing.

The questionnaire survey which aimed to identify the consumer behaviour and the interest in FSC or PWFC certified products contained 14 questions. The authors examined various hypotheses listed in Table 2, regarding the data collected by means of the questionnaire surveys, which needed to be specified prior to the presentation of the results. The results presented in the article represent the opinions of consumers depending on their gender, age, education and income. The purpose of the results was to confirm or reject the following hypotheses in particular:

Table 2. Hypotheses which were set for the questionnaire survey of consumer behaviour.

\begin{tabular}{ll}
\hline & Hypothesis \\
\hline $\mathrm{CBH}_{0}(1)$ & $\begin{array}{l}\text { The preference of the environmental interest in the products made of wood and wood } \\
\text { materials depends on gender. }\end{array}$ \\
\hline $\mathrm{CBH}_{0}(2)$ & $\begin{array}{l}\text { A more environmentally-sensitive group of population can be defined based on the age } \\
\text { structure of the respondents. }\end{array}$ \\
\hline $\mathrm{CBH}_{0}(3)$ & The consumer's income plays a decisive role in preferring value-added products. \\
\hline $\mathrm{CBH}_{0}(4)$ & $\begin{array}{l}\text { Knowledge of the FSC and PEFC certification systems influences the decision-making in } \\
\text { preferring value-added products. }\end{array}$ \\
\hline $\mathrm{CBH}_{0}(5)$ & $\begin{array}{l}\text { The preference of environmental aspects of products made of wood or wood materials } \\
\text { affects the willingness to pay a price premium for value-added products. }\end{array}$ \\
\hline
\end{tabular}

Procedure for creating a questionnaire for business entities:

- The practical part of the project involved creating a database of subjects active in the selected sector and assessing the selected socio-economic indicators using a nation-wide sample of respondents.

- The database of subjects active in the wood processing industry was modelled based on the Classification of Economic Activities (CZ-NACE), which is also used for data evaluations by the Czech Statistical Office and the Ministry of Industry and Trade. These subjects were subsequently divided into groups depending on whether they have incorporated certification systems in their company strategies or not.

- The final stage of the practical preparation of the project included a formulation of such a questionnaire concept which would guarantee sufficient response from the respondents and which would provide the most relevant information about the current issues of certification systems from the business subjects of the selected industry. 
The questionnaire survey which aimed to analyse the socioeconomic impacts of the FSC and PEFC certification on business entities in the timber products segment contained 21 questions. In order to identify the economic impacts, the questions mainly focused on the economic effects of the acceptance of the certification systems expressed by means of the ROE (Return on Equity), the annual turnover, the economic result, the sales, the profit, the rentability of investments and other criteria. The socioeconomic part of the questions targeted at the identification of the most important criteria which resulted in accepting or rejecting the implementation of the certification system by the business entities. The socioeconomic aspect of the analysis also included the link between the social responsibility and the FSC and PEFC certification. The following hypotheses listed in Table 3 are related to the questions included in the questionnaire were formulated for the outputs of the second project idea:

Table 3. Hypotheses which were set as the frame for the questionnaire survey of business entities.

\begin{tabular}{ll}
\hline & Hypothesis \\
\hline $\mathrm{BEH}_{0}(1)$ & There is a dependency between the social responsibility and the FSC and PEFC certification. \\
\hline $\mathrm{BEH}_{0}(2)$ & $\begin{array}{l}\text { The costs of the certification are the most important reason which discourages business } \\
\text { entities from its implementation. }\end{array}$ \\
\hline $\mathrm{BEH}_{0}(3)$ & $\begin{array}{l}\text { The certification systems are often accepted mainly due to pressures exerted by interest } \\
\text { groups, public and customers (consumers). }\end{array}$ \\
\hline $\mathrm{BEH}_{0}(4)$ & $\begin{array}{l}\text { Business entities most often perceive the certification as a market incentive and a tool for } \\
\text { streamlining sales. }\end{array}$ \\
\hline $\mathrm{BEH}_{0}(5)$ & A long-term use of the certification increases the economic effectiveness of the certification. \\
\hline $\mathrm{BEH}_{0}(6)$ & The Czech enterprises mainly consider the certification systems ineffective. \\
\hline
\end{tabular}

All the above-mentioned hypotheses were formulated with respect to the questions used in the questionnaires; they aimed to clearly prove the impacts, causes, consequences and links between the individual parameters which were analysed in connection with the FSC and PEFC certification systems.

\section{Results}

\subsection{Analysis of Consumer Behaviour}

The results interpreted in this section were obtained by means of the analysis of the respondents' consumer behaviour with respect to a recognition of and interest in certified wood raw material. The outputs should have rejected or not rejected the hypotheses formulated in Materials and Methods section of this article. When assessing the $\mathrm{CBH}_{0}(1)$ hypothesis, the respondent's gender was in the contingency with the answers to the question: "Are you interested in the environmental aspects of the production of products made of wood or wood materials (recycling, the material used, method of processing, etc.)?" Considering the results shown in Table 4, the $\mathrm{CBH}_{0}(1)$ hypothesis was rejected.

Table 4. Results of the questionnaire survey for the $\mathrm{CBH}_{0}(1)$ hypothesis.

\begin{tabular}{ccccc}
\hline Answer to the Question & Male & Percentage & Female & Percentage \\
\hline "Yes" & 124 & $62.3 \%$ & 130 & $63.4 \%$ \\
"No" & 68 & $34.2 \%$ & 71 & $34.6 \%$ \\
Without answer & 7 & $3.5 \%$ & 4 & $2 \%$ \\
\hline Answers total & 199 & $100 \%$ & 205 & $100 \%$ \\
\hline
\end{tabular}

Based on Table 4, it can be said that the dependence of the environmental interest in products made of wood or wood material on gender was not significant; therefore, the $\mathrm{CBH}_{0}$ (1) hypothesis was rejected. 
In the case of the $\mathrm{CBH}_{0}$ (2) hypothesis, the age groups were assessed in the contingency with the answers to the question: "How important is it for you whether a product made of wood or wood materials is also produced in line with nature protection and conservation?" Based on Table 5, the $\mathrm{CBH}_{0}(2)$ hypothesis can be partially not rejected since the environmental interest shown by opting for products produced in line with nature protection and conservation was substantially higher in the case of the respondents aged over 40. Taking account of the percentages, these facts were proved by the ratio of the total number of respondents: this criterion was marked as a priority by each sixth respondent in the age group of $40-54$ years $(16.1 \%)$, each forth respondent in the case of the age group of 55-64 (24.3\%), and almost each third respondent (30\%) in the age group of 65 years or more. To not reject this hypothesis completely, it is necessary to add respondents to the individual age groups so that there is roughly the same number of respondents in each group.

Table 5. Results of the questionnaire survey for the $\mathrm{CBH}_{0}(2)$ hypothesis.

\begin{tabular}{|c|c|c|c|c|c|c|}
\hline \multirow{2}{*}{ Answer to the Question } & \multicolumn{6}{|c|}{ Age Group } \\
\hline & 0-17 & $18-25$ & $26-39$ & $40-54$ & $55-64$ & 65 and More \\
\hline "yes, it is a priority" & 2 & 16 & 8 & 18 & 9 & 6 \\
\hline "yes, if somebody recommends it to me" & 0 & 25 & 14 & 16 & 9 & 1 \\
\hline "no, I am not very interested in it" & 3 & 21 & 11 & 14 & 4 & 5 \\
\hline "no, unless I see it written somewhere" & 1 & 6 & 6 & 5 & 1 & 0 \\
\hline "I sometimes take interest in it" & 1 & 27 & 42 & 39 & 7 & 4 \\
\hline "yes, if there is a verified expert justification for it" & 1 & 22 & 13 & 19 & 6 & 3 \\
\hline Without answer & 1 & 0 & 3 & 1 & 1 & 1 \\
\hline Number of respondents in age group & 9 & 117 & 97 & 112 & 37 & 20 \\
\hline
\end{tabular}

In the case of the $\mathrm{CBH}_{0}$ (3) hypothesis, the respondents categorised into groups based on their income were assessed in the contingency with the answers to the question: "If you could choose between two timber products (furniture, paper products, wood material, wooden houses), would you prefer the more expensive product which is environmental friendly to the cheaper product without the added value?".

Table 6 reveals that 70\% of the respondents with their income between 41,000 and 50,000 CZK (czech crowns) and $62.5 \%$ of respondents with their income beyond 51,000 preferred a more expensive value-added product to a cheaper product with no added value. The percentage of respondents who preferred such products decreased with the decreasing income of the respondents. The lower income was obviously the reason why the criterion of the value added to the product was assessed in comparison with the difference in the price of the product with no added value. Almost $51 \%$ of the respondents with their income of up to $10,000 \mathrm{CZK}$ as well as $49 \%$ of the respondents with their income between 11,000 and 20,000 and $37 \%$ of the respondents with their income between 21,000 and 30,000 decided based on the price difference. Therefore, the $\mathrm{CBH}_{0}(3)$ hypothesis was not rejected.

Table 6. Results of the questionnaire survey for the $\mathrm{CBH}_{0}$ (3) hypothesis.

\begin{tabular}{|c|c|c|c|c|c|c|}
\hline \multirow{2}{*}{ Answer to the Question } & \multicolumn{6}{|c|}{ Gross Monthly Income in CZK } \\
\hline & $0-10,000$ & $11,000-20,000$ & $21,000-30,000$ & $31,000-40,000$ & $41,000-50,000$ & $\begin{array}{c}\text { More Than } \\
51,000\end{array}$ \\
\hline "yes, I would prefer it" & 27 & 24 & 34 & 2 & 7 & 5 \\
\hline "no, I would not prefer it" & 14 & 12 & 8 & 1 & 0 & 1 \\
\hline "I would prefer it based on an expert justification" & 23 & 33 & 13 & 9 & 0 & 2 \\
\hline "it would depend on the price difference" & 66 & 67 & 33 & 6 & 1 & 0 \\
\hline Without answer & 0 & 0 & 1 & 0 & 2 & 0 \\
\hline Number of respondents & 130 & 136 & 89 & 18 & 10 & 8 \\
\hline
\end{tabular}

In the case of the $\mathrm{CBH}_{0}$ (4) hypothesis, the question no. 1: "Do you know the meaning of the FSC or PEFC logo?" was selected for the data contingency; the answers to this question were assessed depending on the willingness to prefer a value-added product (question no. 2) in the form of a certified product. 
Taking into consideration the data provided in Table 7, it was possible to say that the $\mathrm{CBH}_{0}(4)$ hypothesis was not rejected. Of the respondents, $53 \%$ preferred a value-added product consequently to recognising a logo, a visual identification of the logo or to an idea evoking the meaning of the logo while $45 \%$ of the respondents decided based on an expert justification and only $34 \%$ of the respondents did not prefer such product. Of the respondents who identified neither the logo nor its meaning, 45\% did not prefer the product and $44 \%$ decided based on the price difference. Hence the recognition of the logo and of its meaning affects the final decision of respondents in preferring environmental aspects.

Table 7. Results of the questionnaire survey for the $\mathrm{CBH}_{0}(4)$ hypothesis.

\begin{tabular}{|c|c|c|c|c|}
\hline \multirow[b]{2}{*}{ Answer to the Question 1} & \multicolumn{4}{|c|}{ Answer to Question 2} \\
\hline & $\begin{array}{l}\text { Yes, I Would } \\
\text { Prefer It }\end{array}$ & $\begin{array}{l}\text { No, I Would Not } \\
\text { Prefer It }\end{array}$ & $\begin{array}{c}\text { I Would Prefer It } \\
\text { Based on Expert } \\
\text { Justification }\end{array}$ & $\begin{array}{c}\text { It Would Depend } \\
\text { on the Price } \\
\text { Difference }\end{array}$ \\
\hline "I know the logo and its meaning" & 17 & 4 & 12 & 33 \\
\hline "I have some idea of the logo meaning" & 15 & 3 & 10 & 36 \\
\hline "I only know the logo" & 21 & 5 & 15 & 28 \\
\hline "I know neither the logo nor its meaning" & 45 & 23 & 42 & 78 \\
\hline Without answer & 2 & 0 & 3 & 1 \\
\hline Number of respondents & 100 & 35 & 82 & 176 \\
\hline
\end{tabular}

The last hypothesis- $\mathrm{CBH}_{0}$ (5) - aimed to assess the justifiability of preferring the environmental interests of consumers with the real willingness to pay a price premium for the added value of certified products. The output information from which the compared data proceeded contained the answers to the question: "What percentage above the price would you be willing to pay for a value-added timber product?" and the interest in the environmental aspect of products made of wood or wood materials.

The results included in Table 8 do not reject the formulated hypothesis $\mathrm{CBH}_{0}(5)$ and show that the environmental interest influenced the consumers' willingness to pay the price difference for a value-added product. Only $5 \%$ of the respondents who prefer the environmental aspect would not be willing to pay a higher price for a value-added product. Of all the respondents, $25 \%$ who did not consider the environmental aspect of a product a reason to prefer the product said that they would not pay a higher price for such a product.

Table 8. Results of the questionnaire survey for the $\mathrm{CBH}_{0}(5)$ hypothesis.

\begin{tabular}{ccc}
\hline \multirow{2}{*}{ Answer to the Question } & I Prefer the Environmental Aspect of Products \\
\cline { 2 - 3 } & Yes & No \\
\hline $0 \%$ & 13 & 34 \\
$1-10 \%$ & 94 & 60 \\
$11-30 \%$ & 117 & 34 \\
$31-50 \%$ & 20 & 7 \\
$51-75 \%$ & 6 & 1 \\
$76-100 \%$ & 4 & 0 \\
more & 0 & 0 \\
Without answer & 0 & 3 \\
\hline Number of respondents & 254 & 139 \\
\hline
\end{tabular}

\subsection{Analysis of Business Entities}

The results presented in this section aim to demonstrate the results of the analysis of socioeconomic impacts on business entities in the timber product segment in the context of the interest in assessing the positive and negative consequences of wood raw material certification. The authors formulated six hypotheses to compare the data obtained from the questionnaire survey. Proceeding from the respondents' answers, these hypotheses should help identify the critical areas of the certification systems. 
The $\mathrm{BEH}_{0}$ (1) hypothesis assessed the social aspect of the certification related to the social responsibility of enterprises. The motive for this hypothesis was to identify the link between the FSC or PEFC label/logo and nature protection with social responsibility. According to the recent survey conducted by "IPSOS CSR" [39], up to 35\% of the Czech population spontaneously recall a specific organisation involved in social responsibility (the survey was carried out with the sample of respondents $n=1009$ ). Hence, social responsibility plays an important role in consumer behaviour as well as in the process of choosing an employer. In the case of the FSC and PEFC certification, only $18 \%$ of the respondents associated the nature and landscape protection with the FSC or PEFC label/logo. Since the population's awareness of social responsibility was quite strong but still its awareness of the specific forms of social responsibility (such as the certification) was very poor, it was necessary to seek ways to create a link between those areas. The answers to the question: "Have you encountered in your business specific product labels which represent socially responsible behaviour and which mean that nature and landscape protection has a high priority in the production of those products?" were used to reject or not reject the $\mathrm{BEH}_{0}(1)$ hypothesis. The contingency was completed with specific ECO labels of products. The results of this comparison are presented in Table 9.

Table 9. Results of the questionnaire survey for the $\mathrm{BEH}_{0}(1)$ hypothesis.

\begin{tabular}{ccc}
\hline \multirow{2}{*}{ Answer to Question } & \multicolumn{2}{c}{ Do You Recognise the Label Which Symbolises Socially Responsible Behaviour? } \\
\cline { 2 - 3 } & Yes & No \\
\hline Ecolabel & 7 & 0 \\
Environment-friendly product & 54 & 2 \\
PEFC & 76 & 6 \\
Fair Trade & 12 & 1 \\
FSC & 64 & 3 \\
Eurlist & 11 & 1 \\
\hline Number of respondents & 104 & 23 \\
\hline
\end{tabular}

In the case of enterprises, there was an obvious link between the social responsibility and the identification of its specific forms based on the logo/label. Therefore, the $\mathrm{BEH}_{0}$ (1) hypothesis could not be rejected for the enterprises since almost $73 \%$ of the respondents who said that they had encountered a logo which represents the socially responsible behaviour also identified the PEFC logo and almost $62 \%$ of the respondents identified the FSC logo.

The $\mathrm{BEH}_{0}$ (2) hypothesis was tested by assessing the data presented in Table 10, which included the answers of enterprises which do not apply the certification in their current business strategy analysed by means of the $\mathrm{BEH}_{0}(1)$ hypothesis. The business entities answered the question: "Providing that your answer to question No. 7 was "No", please specify your reasons which discourage you from applying the ECO-philosophy in your business."

Table 10. Results of the questionnaire survey for the $\mathrm{BEH}_{0}(2)$ hypothesis.

\begin{tabular}{lcc}
\hline \multicolumn{1}{c}{ Answers to the Questions } & Number of Answers & Percentage \\
\hline Competitive disadvantage due to higher price of products & 17 & $13.40 \%$ \\
\hline Increased operational costs & 31 & $24.40 \%$ \\
\hline Consumers' disinterest in such products & 22 & $17.30 \%$ \\
\hline Poor legislative support & $7.10 \%$ \\
\hline I do not consider this area of business important (more aspects) & $17.40 \%$ \\
\hline I do not know ECO labelling, therefore I do not prefer it & 9 & $7.10 \%$ \\
\hline $\begin{array}{l}\text { Poor marketing support of the ECO labels and the consumers' lack of } \\
\text { knowledge }\end{array}$ & 14 & $11 \%$ \\
\hline Poor initiative of interest groups to promote this philosophy globally & 8 & $6.30 \%$ \\
\hline Other reasons (please specify) & 8 & $6.30 \%$ \\
\hline
\end{tabular}


Considering the answers provided in Table 10, the $\mathrm{BEH}_{0}$ (2) hypothesis was not rejected. The operational costs were the most important criterion of the disinterest of the Czech business entities in the certification systems.

The project outputs were also linked with the $\mathrm{BEH}_{0}(3)$ and $\mathrm{BEH}_{0}(4)$ hypotheses. These hypotheses were tested using the results shown in Table 11, which presents the evaluation of companies' grounds for implementing the certification. The evaluation scale for each ground was 1-5, where level 1 meant no influence on the decision, 2 represented a slight influence on the company's decision, 3 was a ground with influence, taken into account by the decision, 4 stood for grounds with an important influence on the decision, and level 5 had grounds with crucial, essential influence on the company's decision.

Table 11. Results of the questionnaire survey for the $\mathrm{BEH}_{0}(3)$ and $\mathrm{H}_{0}(4)$ hypotheses.

\begin{tabular}{cccccc}
\hline Ground & \multicolumn{5}{c}{ Evaluation Scale } \\
\cline { 2 - 6 } & $\mathbf{1}$ & $\mathbf{2}$ & $\mathbf{3}$ & $\mathbf{4}$ & $\mathbf{5}$ \\
\hline Ethic ground: "it's the right thing" & 12 & 8 & 18 & 13 & 9 \\
Effort to gain better pubic reputation & 17 & 9 & 12 & 14 & 8 \\
Keeping up with competitors and market & 9 & 2 & 7 & 19 & 26 \\
Application of ethic code & 13 & 7 & 20 & 12 & 9 \\
Effort to increase customers' loyalty & 11 & 6 & 21 & 6 & 14 \\
Effort to gain a competitive advantage & 9 & 6 & 9 & 13 & 22 \\
Effort to minimize losses by irresponsible product using & 16 & 10 & 14 & 10 & 10 \\
It belongs to our PR/marketing & 15 & 9 & 15 & 9 & 10 \\
Effort to attract and keep high quality employees & 32 & 11 & 8 & 1 & 7 \\
External pressure-public, media, consumers & 17 & 6 & 13 & 9 & 14 \\
Effort to improve relationship with a public administration & 25 & 9 & 15 & 3 & 6 \\
Effort to improve the economic performance & 19 & 10 & 10 & 7 & 13 \\
Pressure of foreign headquarters & 35 & 3 & 5 & 3 & 8 \\
Customers' requirement & 7 & 2 & 5 & 14 & 36 \\
Other grounds & 13 & 2 & 7 & 1 & 1 \\
\hline
\end{tabular}

Based on the results provided in Table 11, the hypotheses $\mathrm{BEH}_{0}(3)$ and $\mathrm{BEH}_{0}(4)$ were not rejected. The respondents answered the question: "What were your reasons (motives) for implementing the certification into your business?" Most often, the customers' requirement for the certification, gaining a competitive advantage, the pressure of public or media and keeping up with the competitors and market requirements were mentioned to be the decisive and crucial motive in deciding on the implementation of the certification. These answers accounted for $20-55 \%$ of the overall number of answers, which meant that they were of high frequency and statistical significance.

In the case of the $\mathrm{BEH}_{0}(5)$ hypothesis, the contingency assessment included the answers to the question: "How long have you been applying the PEFC or FSC certification in your business?" and the percentage increase in the individual economic indicators such as sales, profit and added value.

On the basis of the results presented in Table 12, it can be said that the effect of the certification on the economic indicators of companies seemed more effective over a longer timeframe; hence, the $\mathrm{BEH}_{0}(5)$ hypothesis was not rejected. Since only 60 respondents of the total number of 127 had implemented the certification, the number of respondents was importantly lower in comparison with the total number of the sample of respondents. The high number of respondents who did not mark any of the possible answers resulted from the fact that the selected question assessed up to 10 indicators and the respondents preferred other ones. The results of the analysis showed that almost $64 \%$ of companies had positive perceptions of the economic effectiveness of the certification systems and $20 \%$ of the companies considered them ineffective.

The last of the hypotheses which the authors formulated was the $\mathrm{BEH}_{0}(6)$ hypothesis, which assessed the justifiability of the certification systems from the perspective of subjective perceptions of the respondents from the Czech Republic. The data which were used to either reject or not reject the hypothesis are listed in Table 13 and were based on the answers to the question: "Do you think that the certification systems fulfil their purpose or that they are only a result of the pressure of environmental groups (EG) and an unnecessary administrative burden?" 
Table 12. Results of the questionnaire survey for the $\mathrm{BEH}_{0}(5)$ hypothesis.

\begin{tabular}{cccc}
\hline \multirow{2}{*}{ Answer to the Question $\mathbf{1}$} & \multicolumn{3}{c}{ Indicators of Economic Efficiency } \\
\cline { 2 - 4 } & Increase in Sales & Increase in Profit & Increase in Added Value \\
\hline "less than 1 year" & $0-5 \%(3)$ & $0-5 \%(2)$ & $6-20 \%(2)$ \\
"1-3 years" & $0-5 \%(3)$ & $0-5 \%(3)$ & $0-5 \%(4)$ \\
"4-5 years" & $0-25 \%(11)$ & $0-25 \%(11)$ & $0-25 \%(11)$ \\
"6-10 years" & $0-15 \%(14)$ & $0-15 \%(11)$ & $0-20 \%(11)$ \\
10 and more years & $0-15 \%(18)$ & $0-10 \%(17)$ & $0-15 \%(17)$ \\
Without answer & 11 & 16 & 60 \\
\hline Number of respondents & 60 & 60 & 60 \\
\hline
\end{tabular}

Table 13. Results of the questionnaire survey for the $\mathrm{BEH}_{0}(6)$ hypothesis.

\begin{tabular}{ccc}
\hline Options & Responses & Percentage \\
\hline Yes, they serve their purpose & 12 & $15.8 \%$ \\
No, they do not serve their purpose & 6 & $7.9 \%$ \\
They are just a result of the pressure exerted by EGs & 29 & $38.2 \%$ \\
\hline Number of respondents & 76 & $59.8 \%$ \\
\hline
\end{tabular}

The $\mathrm{BEH}_{0}$ (6) hypothesis could not be rejected due to the absolute majority of negative responses of the total of 76 respondents. Only $15.8 \%$ of the respondents thought that the certification systems fulfilled their purpose. Since the respondents who did not employ the certification could also answer this question, the percentage of respondents was thus based on the total of 127 respondents and represented the opinion of the absolute majority of all the respondents who participated in the questionnaire survey.

\section{Discussion}

The environmental interests of society increase pressure on producers and processors to manage both renewable and non-renewable resources in economical and sustainable manner. Consequently, environmental marketing strategies proceed well and make their way into all sectors. Still environmental marketing can only be successful if industry proactively builds mechanisms of trustworthy communication with consumers [40]. The research surveys addressed in this article mediated such communication with consumers via a specific sign (a logo) and its environmental aspects. In forest management, which was the key sector examined in the performed analyses, the tools which can be seen as a form of environmental marketing and representing the sustainability interests are the FSC and PEFC certifications. The results presented in this article had a specific focus. While studies carried out by some foreign authors who examined this issue (e.g., References [41-43]) were focused on the area of consumer's decisions with respect to their willingness to pay an added value in the form of a higher price of certified products and dealt with the criteria affecting those decisions, the consumer behaviour analysis included in this study aimed to establish a link between the environmental interests of the society and the actual willingness to prefer products with environmental aspects with respect to gender, age, income group and awareness of the certification label (logo). The information about the environmental interests of the society was based on the outputs of the representative opinion poll on Czech public's relation to nature and environment conducted by Krajnhanzl et al. [44]. Compared with the results from the selected sector we interpreted, those outputs only differed in the case of gender. According to the results obtained by Krajhanzl et al., a typical person with environmental beliefs is a woman thanks to their majority representation of $59 \%$. This finding was not confirmed by the results we interpreted since the percentage of answers demonstrating environmental interests in the case of timber products was almost equal with both men and women in terms of their numbers. Another source of information with the character of a comparative material was the survey carried out by Ipsos CSR and Reputation [39], which served as the basis for the formulation of the $\mathrm{BEH}_{0}$ (5) hypothesis. 
Regarding its results, the survey supported the results obtained from the selected sector as it showed that $68 \%$ of Czech population would pay a higher price for an eco-friendly product, which was also supported by not rejecting the $\mathrm{BEH}_{0}(5)$ hypothesis. The outputs of the analysis of socio-economic impacts of certification on businesses were verified on the basis of surveys carried out abroad, namely in the USA, Turkey, China, Sweden, Croatia and the Czech Republic, and of the results obtained from the study conducted by KPMG. A part of the results presented in this article established a link between sustainability, environmental interests and environmental protection and social responsibility of businesses via selected labels (logos) which represent such qualities. Building on the latest global study conducted by KPMG (Survey of Corporate Responsibility Reporting 2017) [45], it is possible to say that the results concur at the international level, too, since more than $43 \%$ of companies of the G250 sample and 39\% of the N100 sample (samples of respondents of KPMG) adopted the concept of interlinking responsible entrepreneurship activities with sustainability goals (SDG) within less than two years since their launch. Hence, it can be argued that the society perceives social responsibility of enterprises and sustainability matters as being very close or even identical areas. Another part of the outputs which should be mentioned in the discussion is the most frequent reasons which discourage enterprises from applying ecophilosophy in their business activities. Publications by foreign authors prevailingly concentrated on monitoring positive and negative aspects of certifications. As for the outputs of this analysis, they were specific thanks to the fact that the survey also addressed the entities which had not implemented the certification despite the strong emphasis put on it by the given sector at both national and international markets. Such entities were included in the sample of respondents in order to identify the reasons for a disinterest in the certification and to reveal the weaknesses of the marketing strategy of the certification systems. The outputs indicated that the disinterest mainly results from increased costs and the lack of interest showed by consumers. The costs of certification were frequently mentioned to be the negative aspect of the certifications, by those companies in particular which did not have the relevant series of the ISO management system or another system which would simplify the process of C-o-C certification (chain of custody certification by the PEFC or the FSC which monitors the flow and origin of timber). Furthermore, forest managers' costs of the FSC and the PEFC certifications were notably higher in the case of small-scale land managers, as confirmed by Mikulová, Hájek, Štěpánková and Ševčík, whose study included 157 forest entities in the Czech Republic. The concepts of conditions for the certification implementation should take account of these facts otherwise the philosophy of being "voluntary for anyone" becomes its modified version of being voluntary for greater entities. The second most frequent reason for a negative opinion on the certification, namely the consumers' disinterest in the certification, was caused by the poor awareness of the actual meaning of the certification labels and of their connection with environment and landscape protection. Attitudes of consumers are highly dependent on the knowledge of basic information about products or on asking for it, which increases the ratio of positive attitude in deciding on opting for the given products, as can be supported by several authors (e.g., References [46-48]). Hence, it is necessary to raise both public and professional awareness and promote information about this sphere to elicit a real interest of the society in such practices so that they could become more than mere marketing tools or market incentives. Concerning the $\mathrm{BEH}_{0}$ (3) hypothesis, the results of the analysis of business entities in the Czech Republic also agreed with the results of other studies. According to some studies (e.g., References [49,50]), the grounds for implementing the certification in business are almost equal with the results obtained in the USA and China. A more substantial difference found in the Czech entities was the most frequent reason of "consumer's requirement", which was the least frequent of all the most frequent answers in the aforementioned mentioned studies. In Croatia, however, the attitude of the business entities is the same as in the case of Czech enterprises, since the certification was most often implemented due to requests of customers [51]. This difference may be caused by wood raw material exports because the Czech Republic is one of the biggest exporters of timber in Europe and Croatia has hit all-time high in timber export, which can cause pressure exerted by the entities for which the timber is intended. By contrast, the Chinese timber market strongly depends on the U.S. 
exports ( $54 \%$ of its total export of raw wood goes to China); this can be the reason of the dissimilarity of the results of the analyses of these two countries. The results presented indicate that the economic efficiency of the certification often causes debates among the interested parties and that direct economic effects of the certification depend on a long-term monitoring of the selected indicators. Because of the sensitivity of information of economic nature, many studies, take the authors (e.g., References [52-56]) as an example, rather focus on general impacts in the form of positive or negative economic effects of certification. The outputs of the analysis presented in the article manifested a difference in the positive and negative effects of certification depending on the duration of the use of the certificate. An assessment of the range of efficiency of the selected indicators showed that the percentual efficiency varied significantly with respect to time. This could be related to the establishment of the companies on the market with certified raw material followed by an increase in the economic indicators. The expansion of certification will continue to depend on support from end-users at all levels and benefits which they will be able to recognise.

\section{Conclusions}

Certification systems are an essential element of the sustainable management strategy in forest management as well as in other areas. The percentage of the certified forest area in the Czech Republic amounts to 1.83 million ha of the total forest area of 2.67 million ha, i.e., to more than $68.5 \%$. Consequently, it has quite a significant effect in the context of natural resources management and of their ensuring for the future thanks to the standards and the specific conditions which the certified entities are to meet.

If the most problematic areas of the FSC and PEFC certification systems are to be identified based on the analysed facts, it can be done focusing on three pillars. The first pillar of the concept of certification systems which fails to fulfil its purpose is the goal to motivate a nation-wide interest in the issue. Consumers, and often even the interested parties, do not have sufficient knowledge of the certification, which consequently becomes rather a marketing tool than a fully-fledged means of achieving sustainability. The consumer behaviour is strongly affected by the brand recognition and by its association with the given product/service. If the consumers' interest is not triggered by their inner conviction that value-added products present a better alternative for the society, the price-quality ratio will still be the decisive factor as demonstrated by the results of the analyses presented in this article. The second pillar which is strongly represented in most of the analyses is the cost of the certification, which often does not reflect the size of the certified subject and seems an ineffective investment compared with the benefits. Third-party certification systems should create an equal footing for the subjects with respect to opting for a certification so that the values it represents were fulfilled equally and without significant restrictions. In a transferred context, the third pillar is the market environment modified by the pressures of the certification systems on the businesses in the selected market. The idea of a voluntary tool which should secure forest ecosystems for future generations is turning into a means of competitive influence, which affects the decisions of large entities on choosing a certification system.

The use of certification systems is supposed to bring effectiveness in terms of a broader range of options for enterprises, forest managers and the society as a whole, which is not always easy to secure. As a result, the certifications are often seemed groundless and become the subject-matter of disputes at the level of national policies and public.

All the analysed facts indicate that the certification system concept has some shortcomings, which need to be selected and eliminated with respect to market requirements and to the needs of all the interested parties (processing enterprises, consumers and economic operators).

Author Contributions: Conceptualization, J.M. and D.B.; methodology, J.M.; validation, A.S., D.B. and J.M.; investigation, D.Š.; resources, D.Š.; data curation, J.M.; writing—original draft preparation, J.F.; writing一review and editing, J.M.; supervision, V.K.; project administration, J.M.; funding acquisition, V.K.

Funding: This research was funded by Internal Grant Agency Mendel University in Brno, grant number LDF_VP_2018037 and by Ministry of Agriculture project No. QK1820358. 
Acknowledgments: The paper was prepared with the support of the Ministry of Agriculture.

Conflicts of Interest: The authors declare no conflict of interest.

\section{References}

1. Country Overshoot Days. Available online: https://www.overshootday.org/newsroom/country-overshootdays/ (accessed on 12 June 2019).

2. Joppart, C. EU Overshoot Day 2019: If EU Consumption Was the Global Norm, the Earth's Yearly Budget Would Be Exhausted on 10 May. Available online: http://www.wwf.eu/?uNewsID=346835 (accessed on 12 June 2019).

3. Eurostat 2019: Development of International Trade in Goods, EU-28, 2008-2018. Available online: https: //ec.europa.eu/eurostat/statistics-explained/index.php/International_trade_in_goods (accessed on 15 July 2019).

4. Mezeřický, V. Enviromentální Politika a Udržitelný Rozvoj [Environmental Policy and Sustainability], 1st ed.; 207 s; Portál: Prague, Czech Republic, 2005; ISBN 80-7367-003-8.

5. Sedmák, R.; Tuček, J.; Bodrechtova, I.; Smreček, I.; Dobršinská, Z.; Holécy, J.; Štěrbová, M.; Šálka, J.; Šulek, R.; Košubová, M.; et al. Správy z Výskumu Lesnickej Fakulty pre Prax [Reports on Research Conducted by the Faculty of Forestry for Practice], 1st ed.; TU: Zvolen, Slovakia, 2018; ISBN 978-80-228-3101-7.

6. FAO. The State of the World's Forests 2018-Forest Pathways to Sustainable Development; Licence: CC BY-NC-SA 3.0 IGO; FAO: Rome, Italy, 2018; ISBN 978-92-5-130561-4.

7. Aké Významné Kalamity v Posledných Rokoch Postihli Naše Lesy? No. 7/2014 [What Great Calamities Have Affected Our Forests in Recent Years?]. Available online: http://www.lesmedium.sk/casopis-letokruhy/ 2014/letokruhy-2014-07/ake-vyznamne-kalamity-v-poslednych-rokoch-postihli-nase-lesy (accessed on 12 June 2019).

8. MŽP (Ministry of the Environment). Zákon o Životním Prostředí (Environmental Law). Sbírka Zákonů Část 4/1992 Sb. (Collection of Laws Part 4/1992). Available online: https://www.mzp.cz/www/platnalegislativa. nsf/5B17DD457274213EC12572F3002827DE/\%24file/Z\%2017_1992.pdf (accessed on 30 September 2018).

9. Bernstein, S. The Compromise of Liberal Environmentalism; Columbia University Press: New York, NY, USA, 2001; ISBN 978-0-231-12037-1.

10. Vlosky, R.P.; Ozanne, L.K.; Fontenot, R.J. A conceptual model of US consumer willingness-to-pay for environmentally certified wood products. J. Consum. Mark. 1999, 16, 122-140. [CrossRef]

11. Cashore, B.; Cornelis van Kooten, G.; Vetinsky, I.; Auld, G.; Affolderbach, J. Private or self-regulation? A comparative study of forest certification choices in Canada, the United States and Germany. For. Policy Econ. 2005, 7, 53-69. [CrossRef]

12. Mikulková, A.; Hájek, M.; Štěpánková, M.; Ševčík, M. Forest certification as a tool to support sustainable development in forest management. J. For. Sci. 2015, 61, 359-368. [CrossRef]

13. Suryani, A.N.; Shahwahid, H.M.; Fauzi, P.A.; Alias, R.; Vlosky, R.P. Assessment of Chain-of-Custody certification costs for sawn wood manufacturers in peninsular Malaysia. J. Trop. For. Sci. 2011, 23, 159-165.

14. Guan, Z.; Xu, Y.; Sheong, J.I. The impact of application of FSC Chain of Custody certification on global wood products trade European. J. Wood Wood Prod. 2019, 77, 633-643. [CrossRef]

15. Guan, Z.; Ip Ping Sheong, J.K. The Restricting Effects of Forest Certification on the International Trade of Wood Products. J. Sustain. For. 2019, 38, 1-18. [CrossRef]

16. Paletto, A.; Notaro, S. Secondary wood manufactures' willingness-to-pay for certified wood products in Italy. For. Policy Econ. 2018, 92, 65-72. [CrossRef]

17. Tricallotis, M.; Gunningham, N.; Kanowski, P. The impacts of forest certification for Chilean forestry businesses. For. Policy Econ. 2018, 92, 82-91. [CrossRef]

18. Pinto, G.F.L.; McDermott, C. Equity and forest certification-A case study in Brazil. For. Policy Econ. 2013, 30, 23-29. [CrossRef]

19. Oprsal, Z.; Harmacek, J.; Pavlik, P.; Machar, I. What Factors Can Influence the Expansion of Protected Areas around the World in the Context of International Environmental and Development Goals? Probl. Ekorozw. 2018, 13, 145-157. 
20. Pechanec, V.; Machar, I.; Pohanka, T.; Oprsal, Z.; Petrovič, F.; Svajda, J.; Salek, L.; Chobot, K.; Filippovova, J.; Cudlin, P.; et al. Effectiveness of Natura 2000 system for habitat types protection: A case study from the Czech Republic. Nat. Conserv. 2018, 24, 21-41. [CrossRef]

21. Machar, I.; Vozenilek, V.; Kirchner, K.; Vlckova, V.; Bucek, A. Biogeographic model of climate conditions for vegetation zones in Czechia. Geografie 2017, 122, 64-82.

22. Simon, J.; Machar, I.; Brus, J.; Pechanec, V. Combining a growth-simulation model with acoustic-wood tomography as a decision-support tool for adaptive management and conservation of forest ecosystems. Ecol. Inform. 2015, 30, 309-312. [CrossRef]

23. Cubbage, F.; Diaz, D.; Yapura, P.; Dube, F. Impacts of forest management certification in Argentina and Chile. For. Policy Econ. 2010, 12, 497-504. [CrossRef]

24. Vidal, N.; Kozak, R.; Cohen, D. Chain of custody certification: An assessment of the North American solid wood sector. For. Policy Econ. 2005, 7, 345-355. [CrossRef]

25. Aguilar, F.X.; Vlosky, R.P. Consumer willingness to pay price premiums for environmentally certified wood products in the US. For. Policy Econ. 2007, 9, 1100-1112. [CrossRef]

26. Kobylka, A. Ekonomické Důsledky Certifikace Lesních Produktů. Produktů [Economic Impacts of Forest Product Certification]. Dissertation Thesis, Mendelova univerzita v Brně Mendel University in Brno, Brno, Czech Republic, June 2010; p. 101.

27. Steiner, B.E.; Peschel, A.O.; Grebitus, C. Multi-Product Category Choices Labeled for Ecological Footprints: Exploring Psychographics and Evolved Psychological Biases for Characterizing Latent Consumer Classes. Ecol. Econ. 2017, 140, 251-264. [CrossRef]

28. Aaker, J.; Fournier, S.; Brasel, S.A. When Good Brands Do Bad. J. Consum. Res. 2004, 31, 1-16. [CrossRef]

29. Grohmann, B. The Effect of Logo Design on Brand Personality Perceptions. ASAC 2008, 29, 143-151.

30. Lieven, T.; Grohmann, B.; Herrmann, A.; Landwehr, J.R.; Tilburg, M.V. The effect of brand design on brand gender perceptions and brand preference. Eur. J. Mark. 2015, 49, 146-169. [CrossRef]

31. Lin, L. The relationship of consumer personality trait, brand personality and brand loyalty: An empirical study of toys and video games buyers. J. Prod. Brand Manag. 2010, 19, 4-17. [CrossRef]

32. Philiastides, M.G.; Ratcliff, R. Influence of branding on preference-based decision making. Psychol. Sci. 2013, 24, 1208-1215. [CrossRef]

33. Taleghani, M.; Almasi, M. Evaluate the factors affecting brand equity from the perspective of customers using Aaker's model. Kuwait Chapter Arab. J. Bus. Manag. Rev. 2011, 1, 64-76. [CrossRef]

34. Aaker, J.L. Dimensions of brand personality. J. Mark. Res. 1997, 34, 347-356. [CrossRef]

35. Keller, K.L. Conceptualising, measuring, and managing customer-based brand equity. J. Mark. 1993, 57, 1-22. [CrossRef]

36. Survesystem Sample Size Calculator. Available online: https://www.surveysystem.com/sscalc.htm (accessed on 15 June 2017).

37. Survio Ekonomické Př́nosy a Negativa Plynoucí z Certifikace FSC a PEFC pro Dřevařský Průmysl a Spotřebitele [Economic Benefits and Negatives Resulting from the FSC and PEFC Certifications for Timber Industry and Consumers]. Available online: https://www.survio.com/survey/d/N9C2H8B1N1J9B4P2G (accessed on 19 September 2018).

38. Survio Spotřebitelské Vnímání Lesnických Certifikačních Schémat FSC a PEFC [Consumer Perception of the FSC and PEFC Forest Certification Systems]. Available online: https://www.survio.com/survey/d/ N9C2H8B1N1J9B4P2G (accessed on 15 June 2017).

39. IPSOS CSR; REPUTATION RESEARCH. Společenská Odpovědnost Firem Ovlivňuje Lidi při Jejich Doporučování a Rozhodování [Social Responsibility of Companies Influences People's Recommendations and Decision-Making]. Available online: https://www.ipsos.com/cs-cz/spolecenskaodpovednost-firemovlivnuje-lidi-pri-jejich-doporucovani-rozhodovani (accessed on 22 March 2018).

40. Hansen, E. Forest certification and its role in marketing strategy. For. Prod. J. 1997, 47, 16-22.

41. Ozanne, L.K.; Vlosky, R.P. Willingness to pay for environmentally certified wood products: A consumer perspective. For. Prod. J. 1997, 47, 39-48.

42. Stern, T.; Schwarzbauer, P. Consumer Behavior towards Eco-Friendly Products Wood Products Certification, Consumer Behavior and Its Climate Policy Potential. In Proceedings of the International Conference on Resource Efficiency in Interorganizational Networks, Göttingen, Germany, 13-14 November 2013. [CrossRef] 
43. Shukri, M.; Awang, N.A.G. Willingness to Pay a Price Premium for Certified Wood Products among Consumers in Malaysia. Pertanika J. Trop. Agric. Sci. 2010, 33, 159-165.

44. Krajhanzl, J.; Chabada, T.; Svobodová, R. Vztah České Veřejnosti k Přírodě a Životnímu Prostředí [Czech Public's Attitutde to Nature and Environment]; A representative opinion poll; Masaryk University: Brno, Czech Republic, 2018; p. 354. ISBN 978-80-210-8967-9.

45. KPMG. Available online: https://cifal-flanders.org/wp-content/uploads/2018/12/Mike-Boonen_NonFinancial-Reporting_ENG_05-02-2019.pdf (accessed on 19 September 2018).

46. Michal, J.; Sujová, A.; Březina, D. The importance of products made of certified wood materials to consumers in the Czech Republic. Forum Sci. Oeconomia 2018, 6, 119-131. [CrossRef]

47. Solomon, M. Consumer Behaviour: A European Perspective; Pearson Education: London, UK, 2016; p. 701, ISBN 9781292116723.

48. Bettman, J. Memory Factors in Consumer Choice: A Review. J. Mark. 1979, 43, 37-53. [CrossRef]

49. Vlosky, R.P.; Ozanne, L.K. Environmental certification of wood products: The U.S. manufacturers perspective. For. Prod. J. 1998, 48, 21-26.

50. Chen, J.; Innes, J.L.; Robert, A.K. An exploratory assessment of the attitudes of Chinese wood products manufacturers towards forest certification. J. Environ. Manag. 2011, 92, 2984-2992. [CrossRef] [PubMed]

51. Klarić, K.; Greger, K.; Klarić, M.; Andrić, T.; Hitka, M.; Kropivšek, J. An Exploratory Assessment of FSC Chain of Custody Certification Benefits in Croatian Wood Industry. Drv. Ind. 2016, 67, 241-248. [CrossRef]

52. Federation of Nordic Forest Owners' Organisations. Effectiveness and Efficiency of FSC and PEFC Forest Certification on Pilot Areas in Nordic Countries. Final report. Savcor Indufor Oy, Helsinki. Mimeo/PDF. 2005. Available online: https://www.iatp.org/sites/default/files/181_2_78311.pdf (accessed on 10 June 2018).

53. Türkoğlu, T.; Tolunay, A. Opinions related to certified forest products of forest products importer companies in Turkey. SDU Fac. For. J. 2013, 14, 95-101.

54. Bratt, C.; Hallstedt, S.; Robèrt, K.H.; Broman, G.; Oldmark, J. Assessment of ecolabelling criteria development from a strategic sustainability perspective. J. Clean. Prod. 2011, 19, 1631-1638. [CrossRef]

55. Gilani, H.R.; Kozak, R.A.; Innes, J.L. The state of innovation in the British Columbia value-added wood products sector: The example of chain of custody certification. Can. J. For. Res. 2016, 46, 1067-1075. [CrossRef]

56. Frederick, C.; Susan, M.; Thresa, H.; Michelle, M.F.C.A. Costs and benefits of forest certification in the Americas. In Natural Resources; Jeanette, B.P., Ed.; Chapter 5, Nova Science Publishers: New York, NY, USA, 2009; pp. 155-183, ISBN 978-1-60456-982-7. 